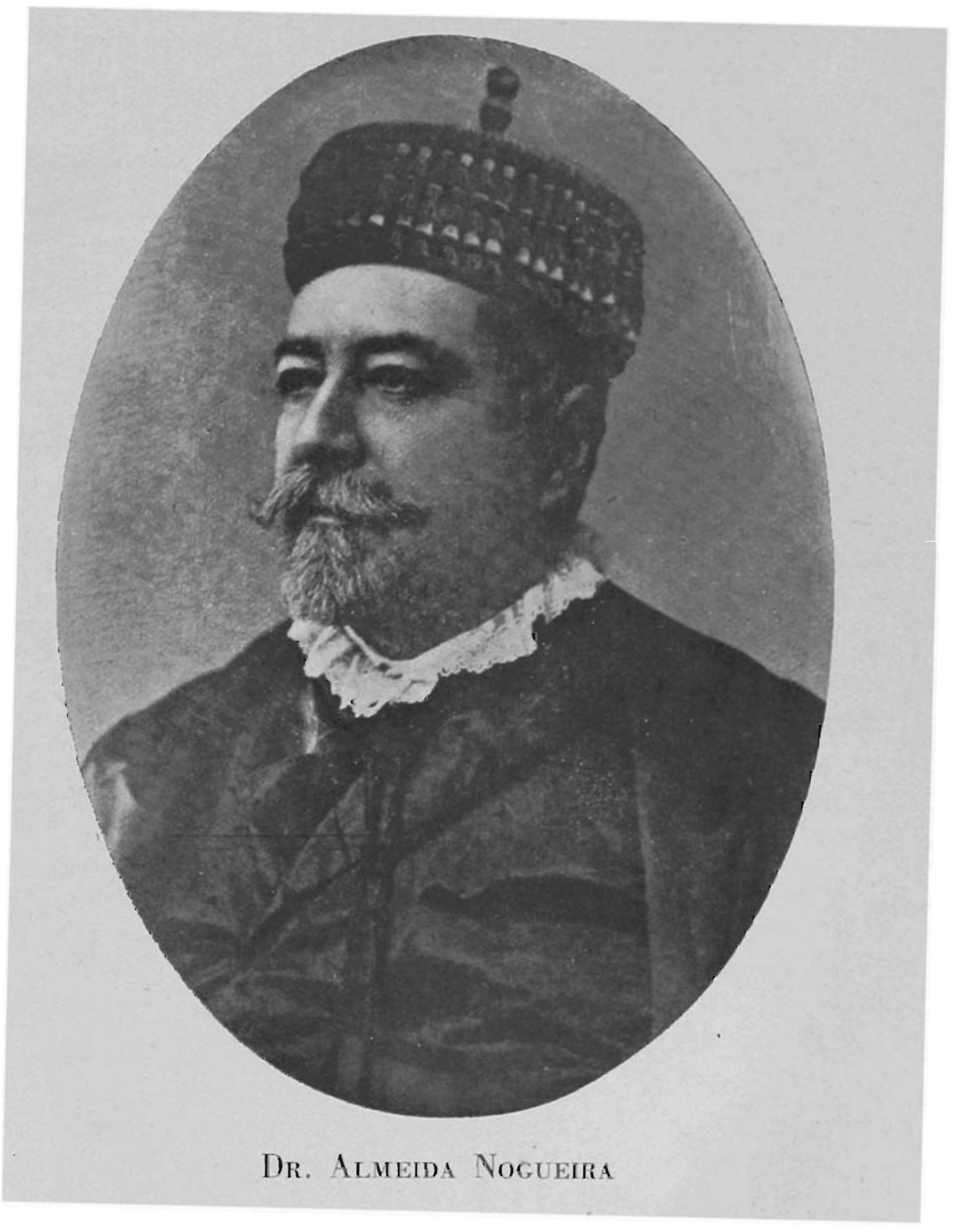




\section{DR. JOSÉ LUIZ DE ALMEIDA NOGUEIRA}

Nasceu, a 4 de Fevereiro de 1851, na fazenda Loanda, em Bananal, pertencente á antiga provincia de S. Paulo, filho do consorcio do Barão de Joatinga e D. Placidia Maria de Almeida. Estudou as primeiras letras em Barra-Mansa, pequena cidade da antiga provincia do Rio de Janeiro, e terminou seu preparo em humanidades no Lyceu Bonaparte, hoje Condorcet, em Paris. Regressando ao Brasil em 1863, concluiu seus estudos para matricular-se em 1869 na Faculdade de Direito de São Paulo. Seu curso foi brilhante, havendo alcançado a approvação com distincção desde que esse grau foi creado por lei. Em Março de 1874, defendeu theses, sendo approvado plenamente e havendo recebido então o grau de doutor. Já no anno anterior fôra eleito deputado á assemblea provincial. Desde essa epocha, não mais abandonou a politica, e a proclamação da republica veio encontral-o na redacção do Correio Paulistano, orgão do partido conservador a que era filiado. Foi notavel sua acção para conseguir a adhesão dos membros do partido ao novo regimen, e a elle deve a republica esse serviço pelo qual ella se consolidou no Brasil. Fez parte no congresso constituinte federal e dos outros congressos nas duas legislaturas seguintes. Foi nomeado lente por decreto, ao tempo da reforma e constituição do corpo docente. A morte o surprehendeu quando ainda no vigor dos annos, desenvolvendo sua actividade, já na cathedra, já no senado estadual. Falleceu a 16 de Julho de 1914. Suas mais importantes obras são o Curso de Economia Politica e as Tradições e Reminiscencias. Dentre os muitos artigos publicados na imprensa e trabalhos ineditos a familia do fallecido destacou alguns, e formou uma obra postuma com o titulo de Estudos Ligeiros. 